\title{
A Very Inconvenient Truth
}

BY CHARLES H. GREENE, D. JAMES BAKER, AND DANIEL H. MILLER

ABSTRACT. Studies conducted after those that contributed to the Intergovernmental Panel on Climate Change (IPCC) Fourth Assessment Report (FAR) suggest that human society may be facing a very inconvenient truth - that emission reduction efforts alone are unlikely to stabilize greenhouse gas concentrations at levels low enough to prevent dangerous anthropogenic interference with the climate system. Here, we discuss reasons why the IPCC process is prone to underestimating the threats of global climate change. We then review some of the critical policy-relevant scientific findings that have emerged since the release of the IPCC FAR. Finally, we discuss how these new findings fundamentally transform the debate on efforts needed to prevent dangerous changes to our climate system. It now appears that to avoid such changes, society will likely need to adopt a mixed strategy of reducing greenhouse gas emissions and employing geoengineering approaches that extract carbon dioxide from the atmosphere and/or reduce the level of incoming solar radiation reaching Earth's surface.

In 1988, the World Meteorological Organization and the United Nations Environment Programme established the Intergovernmental Panel on Climate Change (IPCC) to evaluate the risks of climate change due to human activities. Since the United Nations Framework Convention on Climate Change in 1992 (UNFCCC, 1992), the principal activities of IPCC have been conducted in working groups charged with evaluating the scientific basis for anthropogenic climate change, assessing the vulnerabilities and risks of society to such changes, and exploring the mitigation and adaptation options available to stabilize greenhouse gas (GHG) concentrations at levels sufficient to prevent dangerous climate change.
The IPCC process is based on consensus building, and while the working groups must evaluate the oftencontroversial scientific, technological, and socio-economic factors relevant to policymakers, the final reports are intended to inform rather than shape policy. Oppenheimer et al. (2007) discuss the conservative nature of this consensus-building process and how it can lead scientists and policymakers to underestimate the structural uncertainties and risks associated with several important but poorly understood threats to the Earth system. Additionally, the IPCC process tends to formalize the approaches employed by both climate and socio-economic modelers so that the discussions of scientists and policymakers frequently become fixated on certain numerical values. A fixation on numerical values, especially ones arrived at without a clear explanation of the uncertainties involved, can lead to policy discussions that overlook important aspects of risk.

At present, many policy discussions focus on the projected values for two critical parameters: the global GHG stabilization level and the average global temperature increase at that level. The former stabilization level corresponds to the GHG concentration, in carbon dioxide $\left(\mathrm{CO}_{2}\right)$ equivalents, that will be reached globally once emissions have been reduced and a stable equilibrium between $\mathrm{CO}_{2}$ sources and sinks is attained. The latter temperature increase is the product of net GHG radiative forcing and climate sensitivity-the amount of temperature increase associated with a doubling of GHG concentration (Charney et al., 1979).

Charles H. Greene (chg2@cornell. edu) is Director, Ocean Resources and Ecosystems Program, Department of Earth and Atmospheric Sciences, Cornell University, Ithaca, NY, USA.

D. James Baker is Director, Global Carbon Measurement Program, The William J. Clinton Foundation, Philadelphia, PA, USA. Daniel H. Miller is Managing Director, The Roda Group, Berkeley, CA, USA. 
In theory, use of the above parameters to inform the policymaking process would appear to be relatively straightforward. However, in practice, they are difficult to use because of the cascade of uncertainties involved (Schneider, 2001). For example, as we attempt to regulate emissions to achieve a particular global GHG stabilization level, there is still considerable uncertainty about how to include a number of nonlinear processes in models that are important in determining climate sensitivity. In addition, even when one is satisfied with projections of the average global temperature increase, there remains considerable uncertainty in assessing the vulnerabilities of various natural and human systems to that increase (IPCC, 2007b). Without a better understanding of these vulnerabilities, it is difficult to assess potential climate threats quantitatively, especially those most relevant to risk management. Therefore, natural and social scientists have found it difficult to define what constitutes dangerous anthropogenic interference with the climate system (Schneider and Lane, 2005). After expert testimony and considerable debate, the European Union decided to adopt an average global temperature increase of $2.0^{\circ} \mathrm{C}$ as its threshold for dangerous climate change (European Commission, 2005). Despite the uncertainties, this threshold was also agreed to at the December 2009 United Nations Climate Change Conference of the Parties 15 (COP 15) in Copenhagen, Denmark.

As policymakers continue to discuss emission scenarios and target values for the GHG stabilization level, the concept of warming in the pipeline (Hansen et al., 2005) has taken on increasing importance. Warming in the pipeline corresponds to the growing gap between the observed value of average global temperature and the expected equilibrium value once various feedback mechanisms are taken into account. At present, average global temperature has increased by $\sim 0.8^{\circ} \mathrm{C}$ above late nineteenth century values. Ramannthan and Feng (2008) suggest that this increase is roughly consistent with $25 \%$ of the committed warming in the pipeline that IPCC models project will unfold during the twenty-first century as heat currently stored in the upper ocean approaches equilibrium with the atmosphere and as the cooling effects of aerosols in the atmosphere are reduced by air pollution abatement laws. Thus, they conclude that, even if GHG emissions were to drop precipitously and concentrations were to stabilize at today's levels, we are already committed to a temperature increase of $2.4^{\circ} \mathrm{C}$ by the end of the century, a warming in excess of there are physical limits on the rate at which new, low-carbon energy technologies can be deployed (Kramer and Haigh, 2009), even assuming that the proper financial incentives are adopted (Galiana and Green, 2009), emissions are unlikely to be reduced substantially for several decades. Therefore, we can anticipate that GHG concentrations will continue to rise for at least the first half of the twenty-first century before eventually stabilizing. Because of $\mathrm{CO}_{2}$ 's long residence time in the atmosphere, the overall GHG concentration in the absence of anthropogenic sequestration efforts will stabilize for the next thousand years at a level that is approximately $40 \%$ of its peak enhancement over the pre-industrial period (Solomon et al., 2009). Even more significantly, Solomon et al. (2009) conclude that the climate warming induced by elevated GHG concentrations is largely irreversible. Once atmospheric temperature reaches equilibrium at a certain peak-overall

\section{S IF SOCIETY IS TO AVOID DANGEROUS CLIMATE CHANGE, THEN THE POLICY DEBATE MUST TRANSITION FROM DISCUSSIONS OF MITIGATION STRATEGIES FOCUSED ALMOST EXCLUSIVELY ON REDUCING GHG EMISSIONS TO DISCUSSIONS OF MIXED STRATEGIES...}

the European Union's threshold for dangerous climate change.

Of course, GHG emissions will not drop precipitously tomorrow and in fact have been increasing more rapidly during recent years than the worstcase scenarios used in previous IPCC reports (Raupach et al., 2007). Because
GHG concentration, it will not drop markedly for the next thousand years even as GHG concentrations decline. This irreversibility comes about because the atmosphere's loss of heat to the ocean is even more gradual than its loss of $\mathrm{CO}_{2}$. The thermal inertia of the ocean, which is delaying the rate of climate warming 
today, will delay the rate of climate cooling in the future. A crucial point for policymakers and the public to recognize is that the global GHG stabilization level reached during the twenty-first century will have climatic consequences for the remainder of the millennium.

The short- and long-term consequences of a particular GHG stabilization level are uncertain due to our limited understanding of the slower feedback mechanisms in the climate system. For example, the committed warming in the pipeline for the twenty-first century discussed previously includes only the relatively rapid feedback mechanisms associated with the ocean's thermal inertia and atmospheric aerosols; it does not take into account the more gradual surface-albedo feedback mechanisms associated with disintegration of the cryosphere and changes in vegetation cover (Hansen et al., 2008). Using estimates from the paleorecord, Hansen et al. (2008) argue that the net GHG radiative forcing,
2002), Hansen et al. (2008) conclude that sea-level rise during the next century might greatly exceed estimates provided by the IPCC Fourth Assessment Report (FAR; IPCC, 2007a,b,c). Lending further support to this conclusion is a recent study reporting that Yucatán coral reefs experienced a sea-level rise of $\sim 3 \mathrm{~m}$ in a century during the previous interglacial period, approximately 121,000 years ago (Blanchon et al., 2009).

A sea-level rise during the twenty-first century comparable to that reported for the last interglacial period would be catastrophic to human society. However, the Greenland and West Antarctic ice sheets are only two among a number of tipping elements that are considered at risk from climate warming during the next few centuries (Lenton et al., 2007). A tipping element is a large-scale component of the Earth system that has the potential to rapidly change state in response to small perturbations that exceed some critical threshold-its tipping point. Society is especially vulnerable to these

\section{...INVESTING IN GEOENGINEERING RESEARCH NOW WILL ENABLE POLICYMAKERS TO MAKE INFORMED DECISIONS BASED ON SCIENCE RATHER THAN UNIFORMED DECISIONS MADE OUT OF DESPERATION.}

including those latter feedback mechanisms, can be twice as high when the cryosphere is in a state comparable to that of today. From these arguments, as well as recent observations of rapid ice sheet disintegration in Greenland (Chen et al., 2006; Howat et al., 2007) and West Antarctica (Rignot and Jacobs, types of nonlinear responses to climate warming because their speed and magnitude make adaptation difficult, if not impossible. Among the policy-relevant tipping elements Lenton et al. (2007) evaluated for their sensitivity to future climate warming, those associated with melting of the cryosphere posed the most imminent threats. Many climate scientists now anticipate a complete seasonal disappearance of Arctic sea ice in the coming decades (Serreze et al., 2007; Wang and Overland, 2009) and significant losses from the Greenland and West Antarctic ice sheets during the next two centuries (Hansen et al., 2005, 2008). Although there are many precedents in the paleorecord of the global meridional overturning circulation (MOC) shutting down in response to major cryospheric disintegration events (Greene et al., 2008), its potential occurrence during the twenty-first century is considered unlikely (Weaver and Hillaire-Marcel, 2004). However, a slowing down of the MOC is considered likely during the present century, and a continued rise in GHG forcing will increase the risk of a complete shutdown in the coming centuries.

For policymakers, there are two important messages to take home from the recent scientific findings that have emerged since the IPCC FAR. First, the climate system is less resilient to GHG forcing than we previously thought (Alison et al., 2009; Sokolov et al., 2009). Greater climate sensitivity to GHG forcing makes the system less resistant to warming, while the ocean's thermal inertia makes that warming essentially irreversible for the next thousand years. Second, there is convincing evidence that the committed warming in the pipeline will not only exceed the European Union's $2.0^{\circ} \mathrm{C}$ threshold for dangerous climate change by the end of the century, it may have already exceeded the tipping point for destabilizing Earth's cryosphere. These new scientific findings, combined with the risks associated with ocean acidification (Doney et al., 
2009), which are not even addressed here, fundamentally transform the current debate on climate mitigation and adaptation policies.

The underlying premise of current climate policy is that society will need to adapt to whatever climate change our mitigation efforts fail to prevent. In recent years, the debate on mitigation goals has focused primarily on reducing GHG emissions to achieve a $\mathrm{CO}_{2}$ stabilization level of 450 ppm or higher (van Vuuren et al., 2007; den Elzen and van Vuuren, 2007). Recent studies by Meinshausan et al. (2009) and Allen et al. (2009) propose that setting mitigation goals that limit cumulative GHG emissions may provide a more practical approach. However, in either case, mitigation efforts that focus only on reducing GHG emissions may be placing society on the hazardous path of having to adapt to dangerous climate change (Parry et al., 2009). A number of climate scientists have argued convincingly that the current $\mathrm{CO}_{2}$ concentration of $\sim 389$ ppm may already have committed society to dangerous climate change by the end of the century (Hansen et al., 2008; reviewed by Monastersky, 2009). Even if that threshold has not been surpassed yet, it is difficult to conceive of society reducing its $\mathrm{GHG}$ emissions in time to prevent such a hazardous commitment (Keith, 2009).

If society is to avoid dangerous climate change, then the policy debate must transition from discussions of mitigation strategies focused almost exclusively on reducing GHG emissions (e.g., IPCC, $2007 \mathrm{~b}$ ) to discussions of mixed strategies that include combinations of reducing GHG emissions and employing geoengineering approaches that extract $\mathrm{CO}_{2}$ from the atmosphere and/or reduce the level of incoming solar radiation reaching Earth's surface (Schneider, 2008; Jones, 2009; Keith, 2009; Morton, 2009). This opinion is consistent with conclusions drawn in a recent report released by the Royal Society entitled, Geoengineering the Climate: Science, Governance and Uncertainty (Royal Society, 2009). The geoengineering options discussed to date by scientists and engineers have not figured prominently in policy discussions because of the perception that they may have detrimental environmental consequences, are prohibitively expensive, or both (Schneider, 2008; Jones, 2009; Morton, 2009; Royal Society, 2009). However, the appropriate course of action is to evaluate the relative financial and environmental costs of each emission reduction or geoengineering option, compare them to the anticipated costs of adaptation if that particular option is not adopted, and then rank them by a set of standards agreed upon by policymakers. IPCC Working Groups II and III should undertake these activities as they prepare the next assessment report.

The initial step in the above process cannot be undertaken without a serious investment in geoengineering research and development. Financial and environmental costs can only be estimated by conducting scalable experiments with reasonable levels of control and replication. As these experiments are scaled up, they will become increasingly difficult to control and replicate. In addition, their financial costs and environmental impacts will likely increase at least proportionally with their scale. Geoengineering experiments will raise serious ethical and legal issues, and society may ultimately decide that most of the proposed approaches cannot be implemented on a global scale because of their anticipated risks to the environment and our socio-economic well being (e.g., ocean fertilization; see Strong et al., 2009). However, investing in geoengineering research now will enable policymakers to make informed decisions based on science rather than uninformed decisions made out of desperation.

\section{ACKNOWLEDGEMENTS}

The authors appreciate the constructive comments provided by the reviewers Dan Sarewitz and Bill Travis. The opinions expressed in this paper are those of the authors and do not necessarily reflect those of the institutions they are affiliated with. 四

\section{REFERENCES}

Alison, I., N.L. Bindoff, R.A. Bindoff, R.A. Bindschadler, P.M. Cox, N. de Noblet, M.H. England, J.E. Francis, N. Gruber, A.M. Haywood, and others. 2009. The Copenhagen Diagnosis, 2009: Updating the World on the Latest Climate Science. University of New South Wales Climate Change Research Centre (CCRC), Sydney, Australia, $60 \mathrm{pp}$. Available online at: http:// www.copenhagendiagnosis.org/ (accessed December 29, 2009).

Allen, M.R., D.J. Frame, C. Huntingford, C.D. Jones, J.A. Lowe, M. Meinshausen, and N. Meinshausen. 2009. Warming caused by cumulative carbon emissions towards the trillionth tonne. Nature 458:1,163-1,166, doi:10.1038/nature08019.

Blanchon, P., A. Eisenhauer, J. Fietzke, and V. Liebetrau. 2009. Rapid sea-level rise and reef back-stepping at the close of the last interglacial highstand. Nature 458:881-885, doi:10.1038/ nature07933.

Charney, J.G., A. Arakawa, D.J. Baker, B. Bolin, R.E. Dickinson, R.M. Goody, C.E. Leith, H.M. Stommel, and C.I. Wunsch. 1979. Carbon Dioxide and Climate: A Scientific Assessment. Report of an Ad Hoc Study Group on Carbon Dioxide and Climate, National Academy of Sciences, The National Academies Press, Washington, DC, 22 pp. Available online at: http://www.nap.edu/openbook. php?record_id=12181\&page=R1 (accessed December 29, 2009). 
Chen, J.L., C.R. Wilson, and B.D. Tapley. 2006. Satellite gravity measurements confirm accelerated melting of Greenland ice sheet. Science 313:1,958-1,960, doi:10.1126/ science.1129007.

den Elzen, M.G.J., and D.P. van Vuuren. 2007. Peaking profiles for achieving long-term temperature targets with more likelihood at lower costs. Proceedings of the National Academy of Sciences of the United States of America 104:17,931-17,936.

Doney, S.C., V.J. Fabry, R.A. Feely, and J.A. Kleypas. 2009. Ocean acidification: The other $\mathrm{CO}_{2}$ problem. Annual Review of Marine Science 1:169-192.

European Commission. 2005. Council of the European Union. Presidency ConclusionsBrussels, 22 and 23 March 2005, 38 pp. Available online at: http://register.consilium. europa.eu/pdf/en/05/st07/st07619-re01.en05. pdf (accessed December 29, 2009).

Galiana, I., and C. Green. 2009. Let the global technology race begin. Nature 462:570-571, doi:10.1038/462570a.

Greene, C.H., A.J. Pershing, T.M. Cronin, and N. Cecci. 2008. Arctic climate change and its impacts on the ecology of the North Atlantic. Ecology 89(11):S24-S38.

Hansen, J., L. Nazarenko, R. Ruedy, M. Sato, J. Willis, A. Del Genio, D. Koch, A. Lacis, K. Lo, S. Menon, and others. 2005. Earth's energy imbalance: Confirmation and implications. Science 308:1,431-1,435, doi:10.1126/ science.1110252.

Hansen, J., M. Sato, P. Kharecha, D. Beerling, V. Masson-Delmotte, M. Pagani, M. Raymo, D.L. Royer, and J.C. Zachos. 2008. Target atmospheric $\mathrm{CO}_{2}$ : Where should humanity aim? Open Atmospheric Science Journal 2:217-231, doi:10.2174/1874282300802010217. Available online at: http://arxiv.org/abs/0804.1126 (accessed December 29, 2009).

Howat, I.M., I. Joughin, and T.A. Scambos. 2007. Rapid changes in ice discharge from Greenland outlet glaciers. Science 315:1,559-1,561, doi:10.1126/science.1138478.

IPCC. 2007a. Climate Change 2007: The Physical Science Basis: Contribution of Working Group I to the Fourth Assessment Report of the Intergovernmental Panel on Climate Change. S. Solomon, D. Qin, M. Manning, Z. Chen, M. Marquis, K. Averyt, M.M.B. Tignor, and H.L. Miller, eds, Cambridge University Press, Cambridge, United Kingdom, and New York, NY, USA, 996 pp. Available online at: http:// www.ipcc.ch/ipccreports/ar4-wg1.htm (accessed December 29, 2009).

IPCC. 2007b. Climate Change 2007: Impacts, Adaptation and Vulnerability: Contribution of Working Group II to the Fourth Assessment Report of the Intergovernmental Panel on Climate Change. M. Parry, O.F. Canziani, J.P. Palutikof, P.J. van der Linden, and C.E. Hanson, eds, Cambridge University Press,
Cambridge, UK, 976 pp. Available online at: http://www.ipcc.ch/ipccreports/ar4-wg2.htm (accessed December 29, 2009).

IPCC. 2007c. Climate Change 2007: Mitigation of Climate Change: Contribution of Working Group III to the Fourth Assessment Report of the Intergovernmental Panel on Climate Change. B. Metz, O.R. Davidson, P.R. Bosch, R. Dave, and L.A. Meyer, eds, Cambridge University Press, Cambridge, United Kingdom, and New York, NY, USA, 851 pp. Available online at: http://www.ipcc.ch/ipccreports/ar4-wg3.htm (accessed December 29, 2009).

Jones, N. 2009. Climate crunch: Sucking it up. Nature 458:1,094-1,097, doi:10.1038/4581094a.

Keith, D.W. 2009. Why capture $\mathrm{CO}_{2}$ from the atmosphere? Science 325:1,654-1,655, doi:10.1126/ science. 1175680 .

Kramer, G.J., and M. Haigh. 2009. Let the global technology race begin. Nature 462:570-571, doi:10.1038/462570a.

Lenton, T.M., H. Held, E. Kriegler, J.W. Hall, W. Lucht, S. Rahmstorf, and H.J. Schellnhuber. 2007. Tipping elements in the Earth's climate system. Proceedings of the National Academy of Sciences of the United States of America 105:1,786-1,793, doi:10.1073/pnas.0705414105.

Meinshausan, M., N. Meinshausen, W. Hare, S.C.B. Raper, K. Frieler, R. Knutti, D.J. Frame, and M.R. Allen. 2009. Greenhouse-gas emission targets for limiting global warming to $2^{\circ} \mathrm{C}$. Nature $458: 1,158-1,162$, doi:10.1038/ nature 08017.

Monastersky, R. 2009. Climate crunch: A burden beyond bearing. Nature 458:1,091-1,094, doi:10.1038/4581091a.

Morton, O. 2009. Climate crunch: Great white hope. Nature 458:1,097-1,100, doi:10.1038/ 4581097a.

Oppenheimer, M., B.C. O’Neill, M. Webster, and S. Agrawala. 2007. The limits of consensus. Science 317:1,505-1,506, doi:10.1126/ science.1144831.

Parry, M., J. Lowe, and C. Hanson. 2009. Overshoot, adapt and recover. Nature 458:1,102-1,103, doi:10.1038/4581102a.

Ramanathan, V., and Y. Feng. 2008. On avoiding dangerous anthropogenic interference with the climate system: Formidable challenges ahead. Proceedings of the National Academy of Sciences of the United States of America 105:14,24514,250, doi:10.1073/pnas.0803838105. Available online at: http://www.pnas.org/ content/105/38/14245.full.pdf + html (accessed December 29, 2009).

Raupach, M.R., G. Marland, P. Ciais, C. Le Quéré, J.G. Canadell, G. Klepper, and C.B. Field. 2007. Global and regional drivers of accelerating $\mathrm{CO}_{2}$ emissions. Proceedings of the National Academy of Sciences of the United States of America 104:10,288-10,293, doi:10.1073/ pnas.0700609104. Available online at: http:// www.pnas.org/content/104/24/10288.full. pdf + html (accessed December 29, 2009).
Rignot, E., and S.S. Jacobs. 2002. Rapid bottom melting widespread near Antarctic ice sheet grounding lines. Science 296:2,020-2,023.

Royal Society. 2009. Geoengineering the Climate: Science, Governance and Uncertainty. The Royal Society, London, $81 \mathrm{pp}$. Available online at: http://royalsociety.org/geoengineeringclimate/ (accessed December 29, 2009).

Schneider, S.H. 2001. What is dangerous climate change? Nature 411:17-19.

Schneider, S.H. 2008. Geoengineering: Could we or should we make it work? Philosphical Transactions of the Royal Society A 366:3,843-3,862.

Schneider, S.H., and J. Lane. 2005. Dangers and thresholds in climate change and the implications for justice. Pp. 23-51 in Justice in Adaptation to Climate Change. N. Adger, J. Paavola, S. Huq, and M.J. Mace, eds, MIT Press, Cambridge, MA.

Serreze, M.C., M.M. Holland, and J. Stroeve. 2007. Perspectives on the Arctic's shrinking sea ice cover. Science 315:1,533-1,536, doi:10.1126/ science.1139426.

Sokolov, A.P., P.H. Stone, C.E. Forest, R. Prinn, M.C. Sarofim, M. Webster, S. Paltsev, and C.A. Schlosser, D. Kicklighter, S. Dutkiewicz, and others. 2009. Probabilistic forecast for $21^{\text {st }}$ century climate based on uncertainties in emissions (without policy) and climate parameters. Journal of Climate 22:5,175-5,204.

Solomon, S., G.-K. Platner, R. Knuttl, and P. Friedlingstein. 2009. Irreversible climate change due to carbon dioxide emissions. Proceedings of the National Academy of Sciences of the United States of America 106:1,704-1,709, doi:10.1073/pnas.0812721106. Available online at: http://www.pnas.org/content/ early/2009/01/28/0812721106.full.pdf+html (accessed December 29, 2009).

Strong, A.L., J.J. Cullen, and S.W. Chisholm. 2009. Ocean fertilization: Science, policy, and commerce. Oceanography 22(3):236261. Available online at: http://tos.org/ oceanography/issues/issue_archive/22_3.html (accessed December 29, 2009).

UNFCCC. 1992. United Nations Framework Convention on Climate Change, Article 2. Available online at: unfccc.int/resource/ docs/convkp/conveng.pdf (accessed January 10, 2010).

van Vuuren, D.P., M.G.J. den Elzen, P.L. Lucas, B. Eickhout, B.J. Strengers, B. van Ruijven, S. Wonink, and R. van Houdt. 2007. Stabilizing greenhouse gas concentrations at low levels: An assessment of reduction strategies and costs. Climate Change 81:119-159.

Wang, M., and J.E. Overland. 2009. A sea ice free summer Arctic within 30 years? Geophysical Research Letters 36, L07502, doi:10.1029/2009GL037820.

Weaver, A.J., and C. Hillaire-Marcel. 2004. Global warming and the next ice age. Science 304:400-402. 